\title{
The modern dam engineer
}

\section{Jonathan Hinks}

Technical Director, HR Wallingford, email j.hinks@hrwallingford.com

Published in the Hydropower and Dams, Issue Six, 2012.

\section{Abstract}

The 12th Geoffrey Binnie Memorial Lecture was given by Jonathan Hinks, at the British Dam Society's 2012 Conference held in Leeds, UK on 13 September 2012. The lecture reflected on the role and benefits of dams, some of the world's outstanding structures, and challenges for today's dam engineers. Mr Hinks draws examples from his personal experience, during his long and distinguished career working as a consulting engineer worldwide.

\section{Keywords}

Dams; reservoirs.

\section{Introduction}

The tradition of having a formal lecture at each British Dam Society conference dates back to 1984, when the first lecture was given by Noel Cochrane. After the death of Geoffrey Binnie in April 1989, the lecture was renamed in his honour.

It should be pointed out that there are two extremely important issues beyond the scope of this lecture. The first is climate change, which represents one of our greatest challenges. The second is the need for sustainable energy from natural resources. Richard Coakley, the President of the Institution of Engineers, stressed this in his Presidential address last November, as did Prince Charles in his lecture at the Institution of Civil Engineers in February 2012.

\section{Dams and their uses}

Dams are no modern invention. The first large dam we know of is Sadd el-Kafara, which was built in Egypt between 2950 and 2600 BC, at the beginning of the Pyramid Age. Some say that it was for flood control, while others believe that it was to supply water to the nearby alabaster quarries. At $14 \mathrm{~m}$ high and $113 \mathrm{~m}$ long, it was nearly a large dam according to the ICOLD definition. It was a huge structure, impounding 500 $000 \mathrm{~m}^{3}$ of water. It did not, however, last very long, as it had a catchment area of $186 \mathrm{~km}^{2}$ and either no spillway or only a very small one.

Unfortunately the builders became rather discouraged after the failure of Sadd el-Kafara, and did not build any more dams for 800 years. 
There were, however, numerous dams in Meso-potamia, although not of the height of Sadd el-Kafara. In about 1800 BC, King Hammurabi of Babylon issued his Code of Laws which included suitable punishments for people who did not keep their dams in proper condition.

Tracing the history of the development of dams from antiquity, through the Roman and Byzantium eras, and from the time of early Persian and Spanish dam building up to the present day, would be fascinating, but this lecture aims to concentrate on recent developments and the work of the modern dam engineer.

Many of the relevant sciences, such as hydrology, have developed very much since World War II; others have changed almost out of recognition. Recently the emphasis on the environmental impact of dams has increased dramatically. There was a major controversy over the merits and challenges of dams, culminating in the establishment of the World Commission on Dams in the 1990s. The controversy continues to some extent today, although the publication of the WCD Report in November 2000 took some of the heat out of it.

The construction of a dam will usually have major impacts, some of which will be favourable and some unfavourable. Furthermore, those that reap the benefits are unlikely to be the same as those that suffer the losses. In recent years there has been a rapidly developing understanding in such areas as the behaviour of riverine fish species and the needs of animals.

I think that everyone in the dams fraternity has become aware of at least some of the issues. In the UK, there has perhaps been less focus on this than in other countries with more vigorous programmes of dam construction, but even here the plans for a $150 \times 106 \mathrm{~m}^{3}$ reservoir near Abingdon were driven as much by environmental considerations as by engineering.

The 50000 large dams in the world hold about $7000 \mathrm{~km}^{3}$ of fresh water, which is about $1000 \mathrm{~m} 3$ for every man, woman and child on the planet. This water is used for irrigation, hydropower, water supply, flood control and navigation. Many of the larger schemes are multipurpose. I will look first at the benefits of these schemes and then at some of the environmental concerns.

Back in 1986 I was one of a team looking at how the increasing population of Bangladesh could be fed in the future. I was horrified by the World Bank population projections, and it has all happened much as predicted. The population of the country was then 90 million. It is now about 164 million and has gone up by at least 3 million since I started preparing this lecture. This talk is not about the world population problem although this cannot be separated from the need for dams. The world population doubled in the 44 years between 1966 and 2010. It is predicted to rise to 9 billion by 2050 .

Table 1: Regional fertility rates

\begin{tabular}{|l|l|}
\hline Region & Total Fertility Rate \\
\hline East Asia & 1.5 \\
\hline Europe & 1.6 \\
\hline North \& Central America & 2.2 \\
\hline South America & 2.2 \\
\hline Australia \& Oceania & 2.5 \\
\hline South Central Asia & 2.8 \\
\hline Western Asia & 3.1 \\
\hline Africa & 4.7 \\
\hline
\end{tabular}


Most of our politicians seem to have consigned this problem to the 'too difficult tray', preferring to talk about climate change, species extinction, shortage of water and shortage of energy, which are really symptoms of the underlying problem. China has tackled the problem head on, with its one child policy, and has 300 to 400 million fewer people than it would otherwise have had.

Of course the increase in population is not uniform. The total fertility rate, which is the number of children a woman can expect to bear in her lifetime, has a replacement level of just over 2.0. The rate is now very low in some countries such as South Korea (1.15), Hong Kong (1.04) and Taiwan (1.03). Regional rates are as shown in Table 1.

It can be seen that in most regions of the world, the total fertility rate still exceeds 2.0. In Africa the rate is 4.7 , which implies that the population will at least triple this century to 3.5 billion. This brings me back to species extinction. For example, there are now less than 800 mountain gorillas left in the wild. Mountain gorillas weigh up to $200 \mathrm{~kg}$ and are magnificent creatures. However, pressure for land is always increasing and the future of many wild animals like these is uncertain.

The rapid increase in world population is also putting huge pressure on the need for food, water supply, energy requirements and flood control to protect the increasing number of people living on floodplains. The various uses of dams can be summarised as follows.

\section{Irrigation}

The largest irrigation schemes are in India, Pakistan, China, Egypt and the USA. Globally irrigated lands total about $2.8 \times 106 \mathrm{~km}^{2} .40$ per cent of the world population gets its food from irrigated lands and 30 to 40 per cent of those people are fed thanks to dams.

The Tarbela dam in Pakistan was completed in 1974 and was built under the 1960 Indus Basin Water Treaty between India and Pakistan. The dam is $143 \mathrm{~m}$ high and $2743 \mathrm{~m}$ long. Figure 1 shows one of the irrigation outlets operating. The reservoir is said to irrigate about $54000 \mathrm{~km}^{2}$ or 30 per cent of Pakistan's irrigated area of about $180000 \mathrm{~km}^{2}$. The original capacity of the reservoir was $14.3 \mathrm{~km}^{3}$.

The other very large dam in the Indus Basin is, of course, Geoffrey Binnie's Mangla dam (see Figure 2) which was completed on the Jhelum river in 1967. Mangla dam was $139 \mathrm{~m}$ high and originally impounded $7.25 \mathrm{~km}^{3}$. Between 2004 and 2009 it was heightened by $9 \mathrm{~m}$, so that it now has a maximum height of $148 \mathrm{~m}$.

The Aswan High dam in Egypt is remarkable for the capacity of the reservoir, which is $111 \mathrm{~km}^{3}$ or almost eight times the original capacity of Tarbela. An area of $8400 \mathrm{~km}^{2}$ is said to have been 'reclaimed' downstream of the dam. 


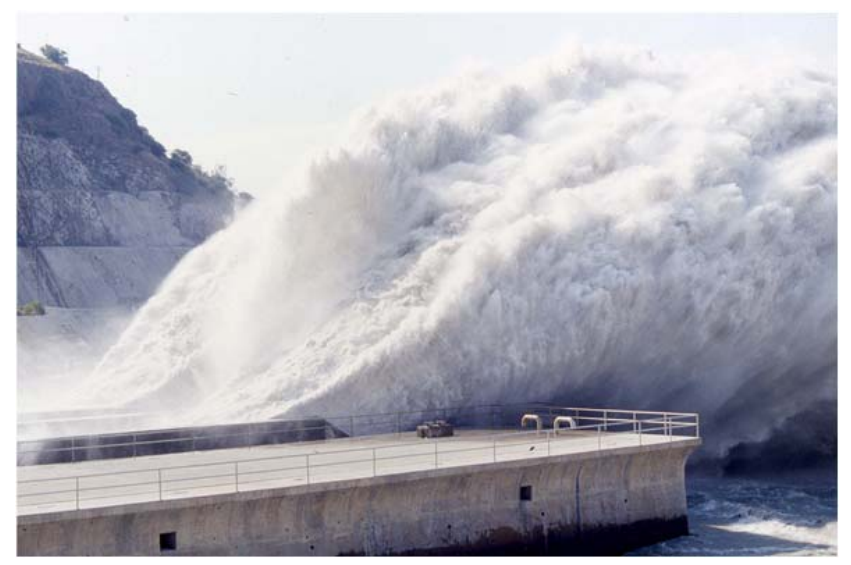

Figure 1: One of the irrigation outlets discharging at the Tarbela dam in Pakistan

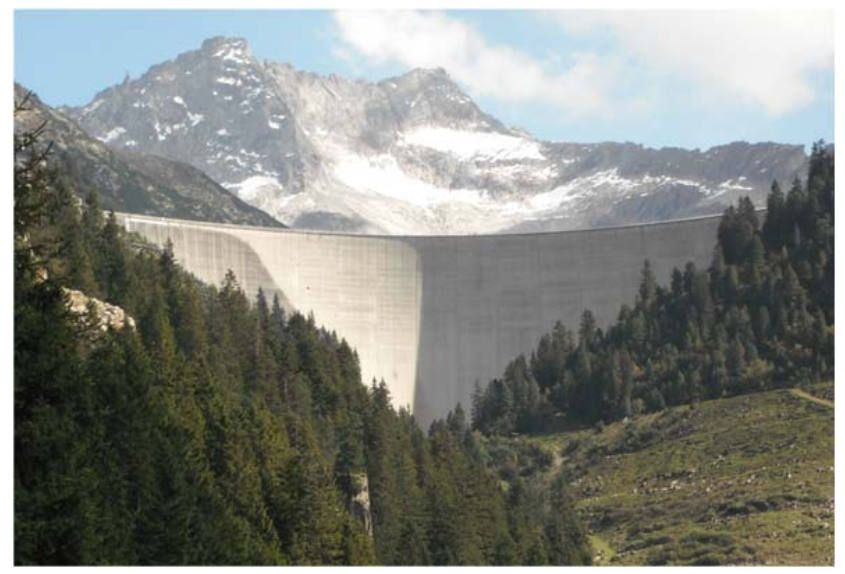

Figure 3: The 186 m-high Zillergründl dam in Austria

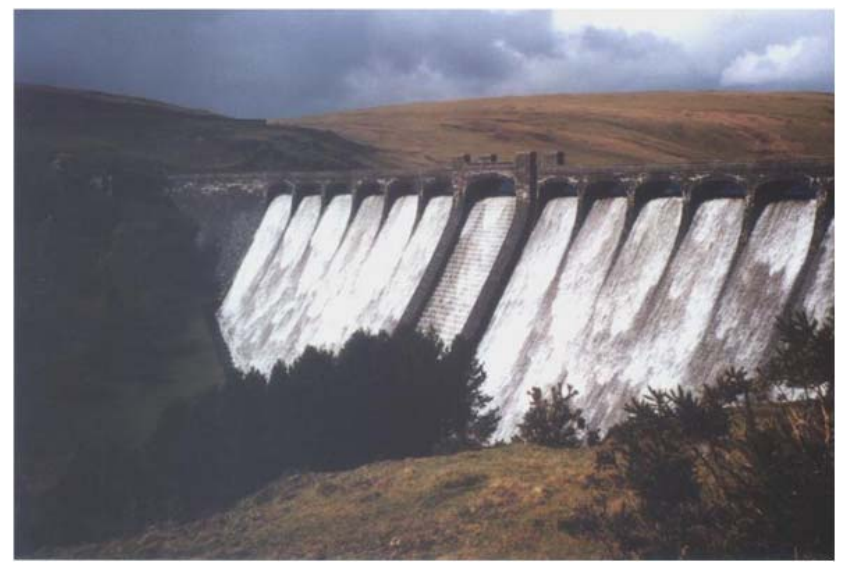

Figure 5: The Claerwen dam, which supplies water to Birmingham, UK

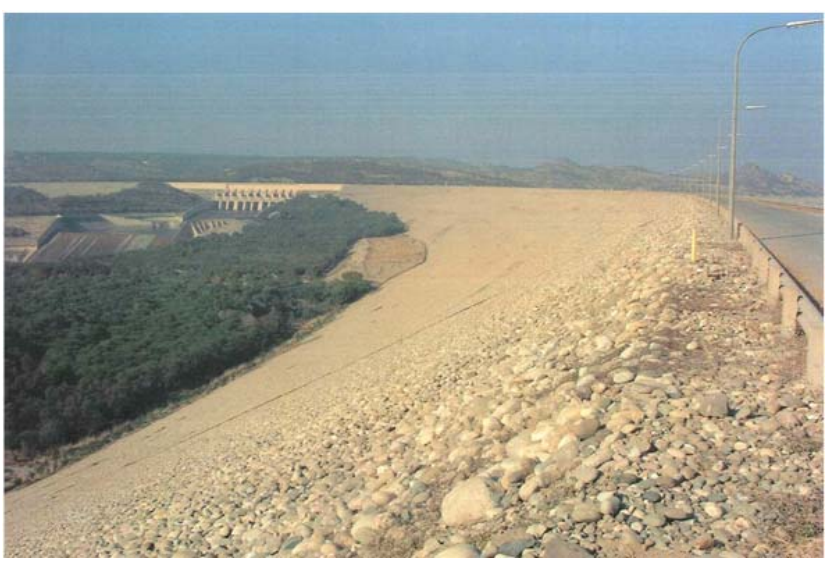

Figure 2: The 148 m-high Mangla dam, Pakistan, completed in 1967 and recently heightened

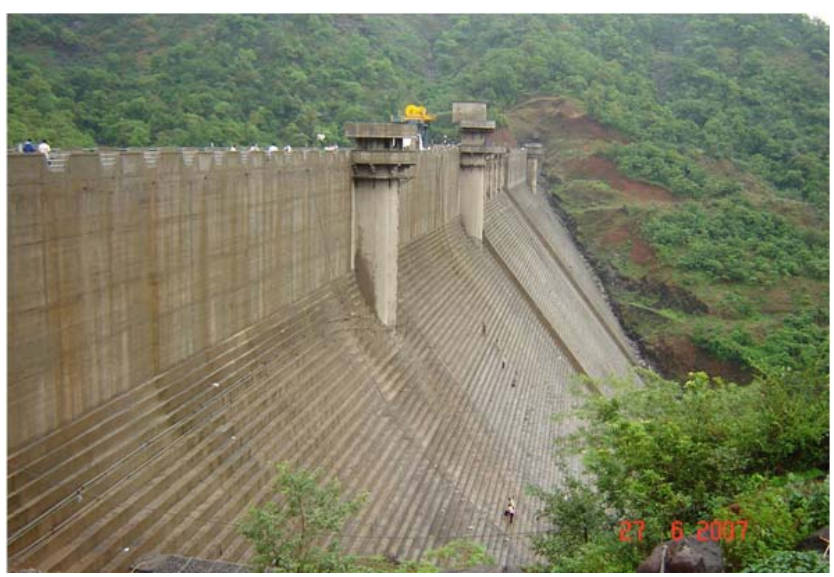

Figure 4: The Lower Ghatghar RCC dam in India, which forms the lower reservoir for a $250 \mathrm{MW}$ pumped-storage scheme

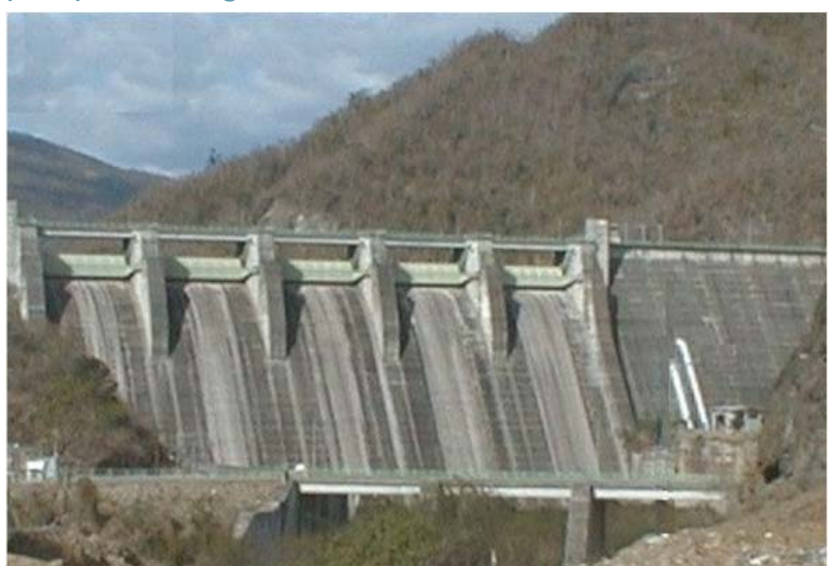

Figure 6: Valdesia dam in the Dominican Republic 


\section{Hydropower}

Many dams are built with hydropower as the prime purpose but the irrigation dams mentioned above also have large generating capacities. Tarbela has an installed capacity of $3478 \mathrm{MW}$ and Mangla, $1644 \mathrm{MW}$. The Aswan High dam has an installed capacity of $2100 \mathrm{MW}$.

Altogether about 17 per cent of the world's electricity is generated by hydropower, a clean, sustainable and renewable resource.

The 186 m-high Zillergründl arch dam in Austria (see Figure 3) is one where the reservoir is used as the upper basin for the $360 \mathrm{MW}$ Häusling pumped-storage scheme.

The 84 m-high Lower Ghatghar RCC dam near Mumbai in India (Figure 4) impounds the lower lake for a 250 MW pumped-storage scheme. Careful thermal analyses were used to show that it would be safe to raise the placing temperature by $3^{\circ} \mathrm{C}$, which saved almost US $\$ 600000$ in the cost of cooling the RCC.

The 14000 MW Itaipu powerplant, on the border between Paraguay and Brazil, still produces more hydropower than any other dam, although the installed capacity is less than Three Gorges in China. It is interesting to note that the area of the reservoir is only $1350 \mathrm{~km}^{2}$ or $0.1 \mathrm{~km}^{2}$ per MW.

\section{Water supply}

There are about 2500 large dams solely for water supply. In the UK, a number of water supply schemes were built in the late 19th century and early 20th century to supply such cities as London, Birmingham, Liverpool, Manchester and Glasgow. Figure 5 shows Claerwen dam, which is one of those supplying Birmingham by gravity via the Elan Aqueduct. It was completed in 1952 and impounds $48.3 \times 106 \mathrm{~m}^{3}$.

Figure 6 shows Valdesia dam in the Dominican Republic. In a study a few years ago, the probability of failure and the cost of failure were calculated for all 24 large dams in the Dominican Republic. The two parameters were then multiplied together to get a risk index equivalent to the annual insurance premium that would be payable for each dam in a perfect market. Valdesia had the fourth highest index, even though there was only one house downstream and only six lives at risk. The reason is that Valdesia supplies most of the 2.2 million inhabitants of Santo Domingo with water, and if this supply were cut off suddenly a very serious situation would result. In due course limited quantities of water could be shipped in from elsewhere, but it would take time to organize this and disease and death could be expected in the meanwhile.

There is, of course, a desperate need for clean water and sanitation in many parts of the world. Some 5000 children under the age of five die each day from waterborne diseases.

It is, however, encouraging that clean water can often be provided quite cheaply, although not necessarily from dams. For example, the British charity Christian Engineers in Development last year completed a gravity scheme with treatment to serve 45000 people in Tanzania at a cost of about $€ 1$ million, equivalent to just about US\$ 30 per head. It is likely that Water Aid and other charities can quote similar figures.

Figure 7 shows the New Victoria dam near Perth in Western Australia. It was commissioned 100 years, to the hour, after the original Victoria dam, which it replaced; some of the guests at the opening ceremony, which followed the original programme, arrived in Victorian dress. The photograph shows two of the next generation of dam engineers, Miss Harriet Hinks and her assistant Miss Thea Hinks, inspecting the dam. 


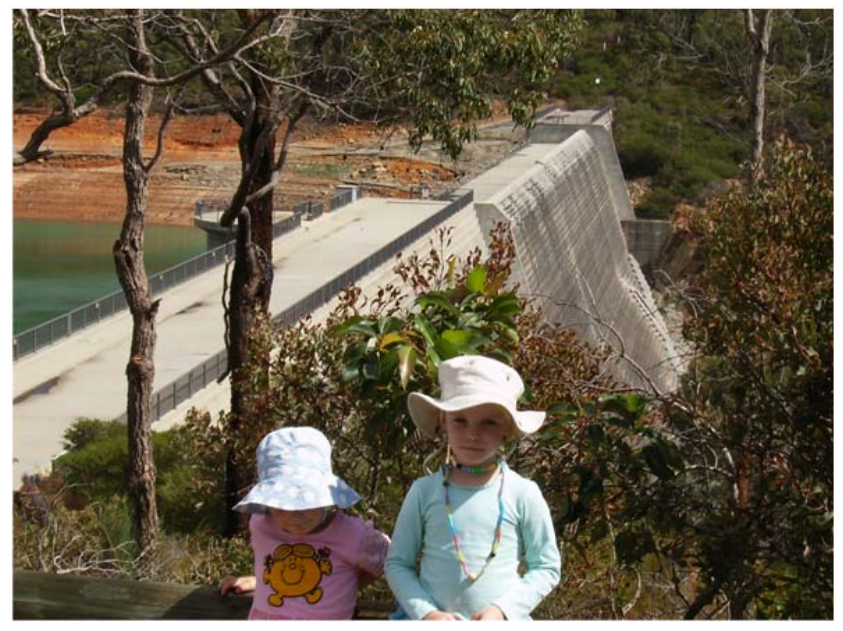

Figure 7: New Victoria dam, Australia. In the foreground: the next generation of dam engineers?

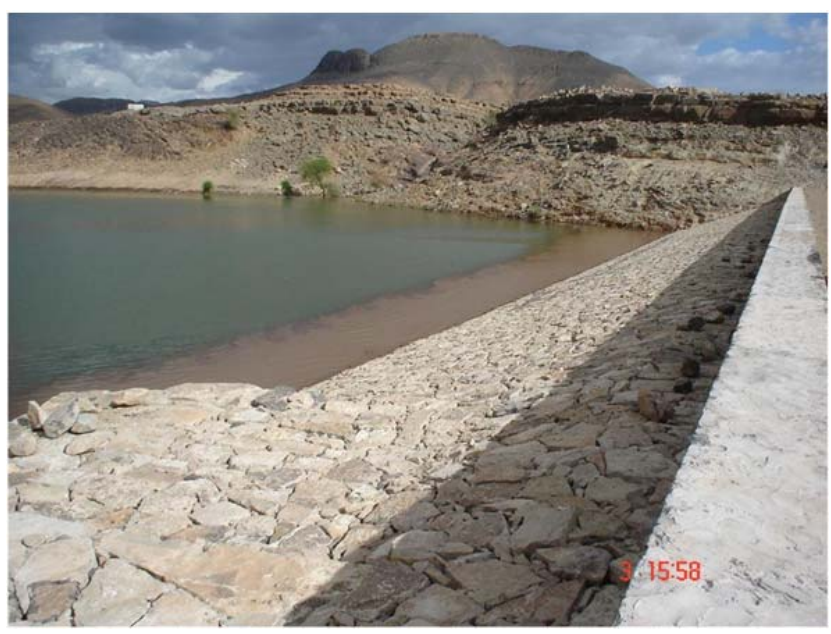

Figure 8: Bani Naji dam in Yemen.

As well as surface water, there is the hugely important issue of groundwater. In many parts of India, Pakistan and China the water table is sinking at a rate of 1-2 m/year. In Sana'a in Yemen, the aquifer is now $200 \mathrm{~m}$ deep and falling fast. The city is $2100 \mathrm{~m}$ above sea level so desalination of seawater is not an option. I have, in the past, suggested the treatment of Sana'a wastewater which is at present polluting the aquifers, but which could be used for irrigation, recharging the aquifers or even (if the quality of treatment could be guaranteed) for domestic supply.

Another option is to catch flash floods in reservoirs, from where they can recharge the aquifers. The sociologist on our Yemen project met the women in the villages and found that they spent much of their time fetching water, and that young girls did not go to school because they had to help with this task. The hope was that, by recharging the aquifers, the dams would assist by allowing the women to go to wells nearer to their homes. Two researchers at Sana'a University recently assessed the project, and found that the refurbishment of Bani Naji dam (Figure 8 ) had a cost recovery period of only 2.9 years. Others were rather longer, but all of the dams seem to have been worth the expenditure. It must be admitted that they put quite a high value $\left(\$ 1.1 / \mathrm{m}^{3}\right)$ on the water, but in view of the serious water shortage there, this could probably be justified.

\section{Flood control}

The peak outflow from a reservoir is always less than the peak inflow. The only exceptions are the rare instances of dambreak or the mis-operation of spillway gates.

Considerably greater flood benefits can be obtained where reservoir levels are kept below the top water level specifically to absorb floods.

Clywedog reservoir, on the headwaters of the Severn river in the UK, is designed for flood control and also to augment dry season flows for the benefit of the towns, which rely on the river for their water supply. The rule curve for operation of the reservoir requires the reservoir to be full at the start of the summer and below a certain level by the start of winter.

There is a similar arrangement at the Three Gorges reservoir on the Yangtze river in China. There the reservoir level is kept $50 \mathrm{~m}$ lower in the summer months to provide $22 \mathrm{~km}^{3}$ of flood storage when the risk of flooding is greatest. Although the Three Gorges project has $18200 \mathrm{MW}$ of installed capacity and a very 
important function in increasing shipping on the Yangtze from 3 million to 50 million tonnes per year, one of its main objectives is flood control. About 30000 people were drowned in the 1954 floods when 1 million were made homeless. There have been five major floods in the last century and the total loss of life is said to be many millions.

In October 1998, the El Cajon reservoir in Honduras absorbed nearly $4 \mathrm{~km}^{3}$ of floodwater from Hurricane Mitch, but as the population struggled with the floodwaters in the Sula Valley, probably nobody noticed this benefit.

Mention should also be made of the many flood storage dams in the UK. Figure 9 shows White Cart Water in Glasgow, built by Glasgow City Council. The flood of 29 November 2011 took place just four weeks after the official opening of the scheme. A total of 230 properties were saved from flooding and about US $\$ 18$ million of water damage was avoided in that incident, which had a return period of between 10 and 25 years.

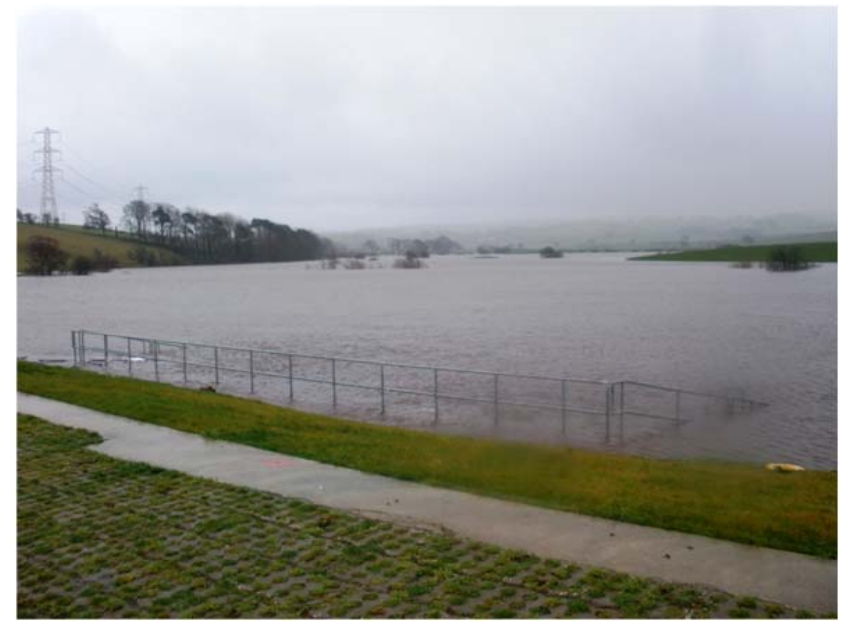

Figure 9: White Cart Water in Glasgow, Scotland, during the flood of 29 November 2011

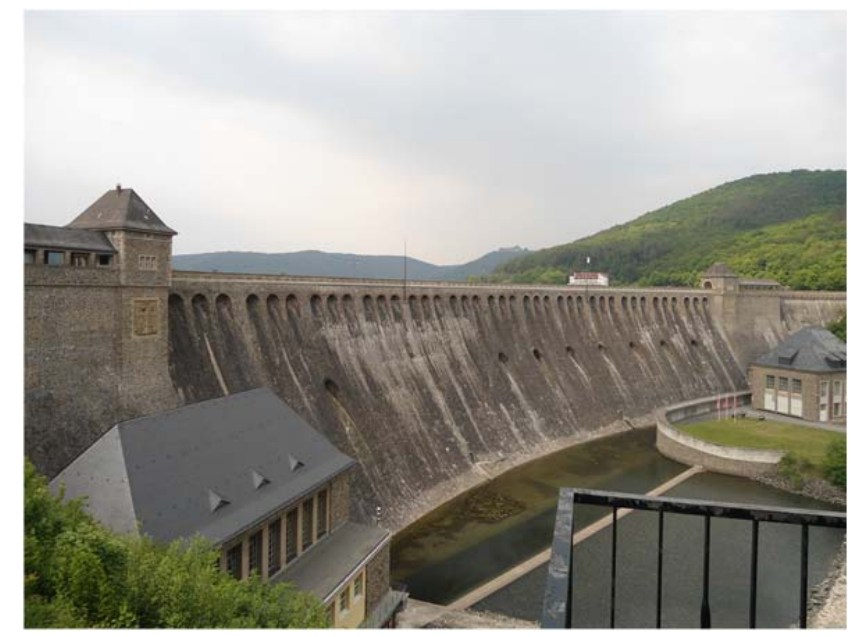

Figure 10: The Eder multipurpose dam in Germany

\section{Navigation}

Dams for navigation in the UK include the 72 large raised reservoirs owned by The Canal \& River Trust. These played a crucial role in the country's Industrial Revolution, and are now important to permit leisure cruising on the canals and as a habitat for fish, birds and other wildlife.

The Eder dam (Figure 10), which supplies the Mittelland canal near Dortmund in Germany, was intended for flood control and also for increasing the water flow in the Fulda and Weser rivers and supplying water for the Mittelland canal. Construction of the canal, which is $325 \mathrm{~km}$ long, began in 1905 with the intention of allowing the passage of barges up to 1000 tons displacement. The canal joins the Elbe-Havel canal, which goes to Berlin and on into Poland.

Another famous navigation waterway is the Panama canal. After early attempts to build a sea level canal had been thwarted by floods in the River Chagres, the idea was formulated to dam the river at Gatun and create a huge reservoir extending a long way across the isthmus. Another large dam, known as the Madden dam, was built further upstream. The Panama canal is now being enlarged with new locks $427 \mathrm{~m}$ long and $55 \mathrm{~m}$ wide. 


\section{Other purposes}

One other example of a use for dams is the Kamuzu barrage, which controls the level of Lake Malawi. The lake has a surface area of $28750 \mathrm{~km}^{2}$, and the barrage, which was completed in 1965, keeps water levels high and maintains a dependable flow down the Shire river, which is the natural outlet from the lake.

Between 1908 and 1935, before the barrage was built, the level of the lake was very low and the flow in the Shire river ceased altogether. The barrage is now being rebuilt to allow water levels in the lake to be raised by $400 \mathrm{~mm}$. This may not sound very much, but it will allow another $11.5 \mathrm{~km}^{3}$ of water to be stored in the lake for the benefit of hydropower schemes along the Shire river (which produce 95 per cent of Malawi's electricity), fishing, irrigation, transport, tourism and wildlife.

\section{Criticisms made against dams}

In its report published in November 2000, the World Commission on Dams highlighted a number of areas of concern. Examples are: resettlement, disturbance to fish, methane emissions, dam safety issues, flooding, cost overruns, sedimentation and reservoir evaporation. Earthquakes and hurricanes, although not mentioned by the World Commission on Dams, deserve a mention as they are very important issues in certain parts of the world. Earthquakes are not covered here in detail, as they are dealt with in other papers presented during the BDS Conference.

\section{Resettlement}

The question of resettlement arises in cases where significant numbers of people have to be moved out of a reservoir area. There is no reliable estimate of how many people have had to be resettled to make way for reservoirs, but figures are available for some major schemes. As examples, about 1.3 million were resettled for the Three Gorges project. It is said that 120000 were resettled for the Aswan High dam and 57000 Tonga people for the Kariba dam in Southern Africa. At Tarbela in Pakistan, 96000 people had to be resettled and some sources claim that some of them have never been given replacement land.

The World Commission on Dams claims that the construction of large dams has led to the resettlement of 40 to 80 million people worldwide, although the justification for these figures appears rather vague. (Indian sources point out that the WCD figure for India is six times the official Indian Government figure). The important question is, however, the quality of the resettlement. Here there has been a lack of good quality data. A resettlement scheme has many components, all of which need to be done well: people need to be provided with a livelihood, houses, water, electricity, schools, clinics and roads. It can well be imagined that sometimes money for these things will be insufficient or planning may be poor, and that people may be left with very low-standard living conditions.

\section{Fish}

Adverse effects on fish catches have been reported on a number of major rivers following the construction of dams, although there are also cases such as Tucurui in Brazil, where significant fisheries have been reported in the new reservoirs. The annual fish harvest at Tucurui had increased to more than 3000 tonnes by 1998 , although worrying levels of mercury (from gold mining operations upstream) have been recorded in 
the fish, which the fishing communities eat 14 times per week. At Aswan, the annual fish harvest was about 35000 tonnes in the mid-1990s.

However the biggest concerns are around migratory fish species. There have been significant falls in catches downstream of many dams, including the Pak Mun dam on a tributary of the Mekong in Eastern Thailand. Adverse impacts are also reported from the Senegal river system, the Niger in West Africa below the Kainji dam, the Lower Volta region, the Nile Delta and on the Zambezi in Mozambique.

Adequately protecting existing fisheries and developing new ones requires great care and knowledge. The detailed design of fish passes may be critical, as is illustrated by experience on the Burnett river in southeast Queensland, Australia. There they recorded 2000 fish from 18 species ascending over a 32 month period. After the introduction of new fish pass arrangements, they recorded 26 times as many fish and twice as many species in about half the time.

The extreme importance of riverine fish as a food source for the very poor has not always been fully recognized and it is vital that these issues be carefully addressed in the planning of future schemes.

\section{Methane}

Methane is, of course, a potent greenhouse gas, and early assertions that hydropower is a benevolent way to generate electricity with respect to greenhouse gases have been challenged. Shallow tropical reservoirs that have not been cleared of vegetation are thought to have the highest emissions of methane; research is continuing on this subject.

The example most often cited is the Balbina reservoir in Brazil. This is a quite exceptional scheme, in that it flooded $2400 \mathrm{~km}^{2}$ to secure an average output of only $112.2 \mathrm{MW}$ with a reservoir of only $12 \mathrm{~km}^{2}$.

In a typical case, hydropower produces much cleaner energy than a fossil fuel station, because there is no sulphur dioxide, nitric oxide, carbon monoxide, dust or mercury which would be associated with coal. It has been estimated that the Tucurui dam in Brazil had only 40 per cent of the impact on global warming of a fossil fuel station of comparable size. This scheme must have methane emissions towards the high end of the scale.

\section{Dam safety issues}

The need for a high standard of dam safety is quite obvious to all. There are about 50000 dams in the world higher than $15 \mathrm{~m}$ or storing more than $3 \times 106 \mathrm{~m} 3$. There were about 200 notable failures in the 20th century, which suggests about one failure per 25000 dam years.

We must, of course, be very careful about how to define 'failure', since for every catastrophic failure involving loss of the stored water, there will be a number of near failures where the dam may be badly damaged.

Figure 11 above shows the Sharredushk dam in Albania after a Magnitude 4.1 earthquake on 18 March 2009. Freeboard was reduced from 1.5 or $2 \mathrm{~m}$ to only $0.1 \mathrm{~m}$, but the contents of the reservoir were not lost. The estimated peak ground acceleration was only $0.07 \mathrm{~g}$.

As part of the Foresight project, we advised the UK Government that the probability of catastrophic failure of one of the 1400 Category A dams in the UK was about 60 per cent in a 50 year period of risk. This implies an average return period for failure of about 75000 years. The return period for serious incidents will be significantly lower. 
It will be seen that I am implying a standard of safety in the UK slightly higher than the world average. This is intentional as we have a good standard of inspections, diligent Supervising engineers and a rather fierce Enforcement Authority. However, we should not get complacent.

The owners of the restaurant in Albania had obviously carried out careful hydrological analyses before deciding to site their restaurant in the spillway at Sharge reservoir!

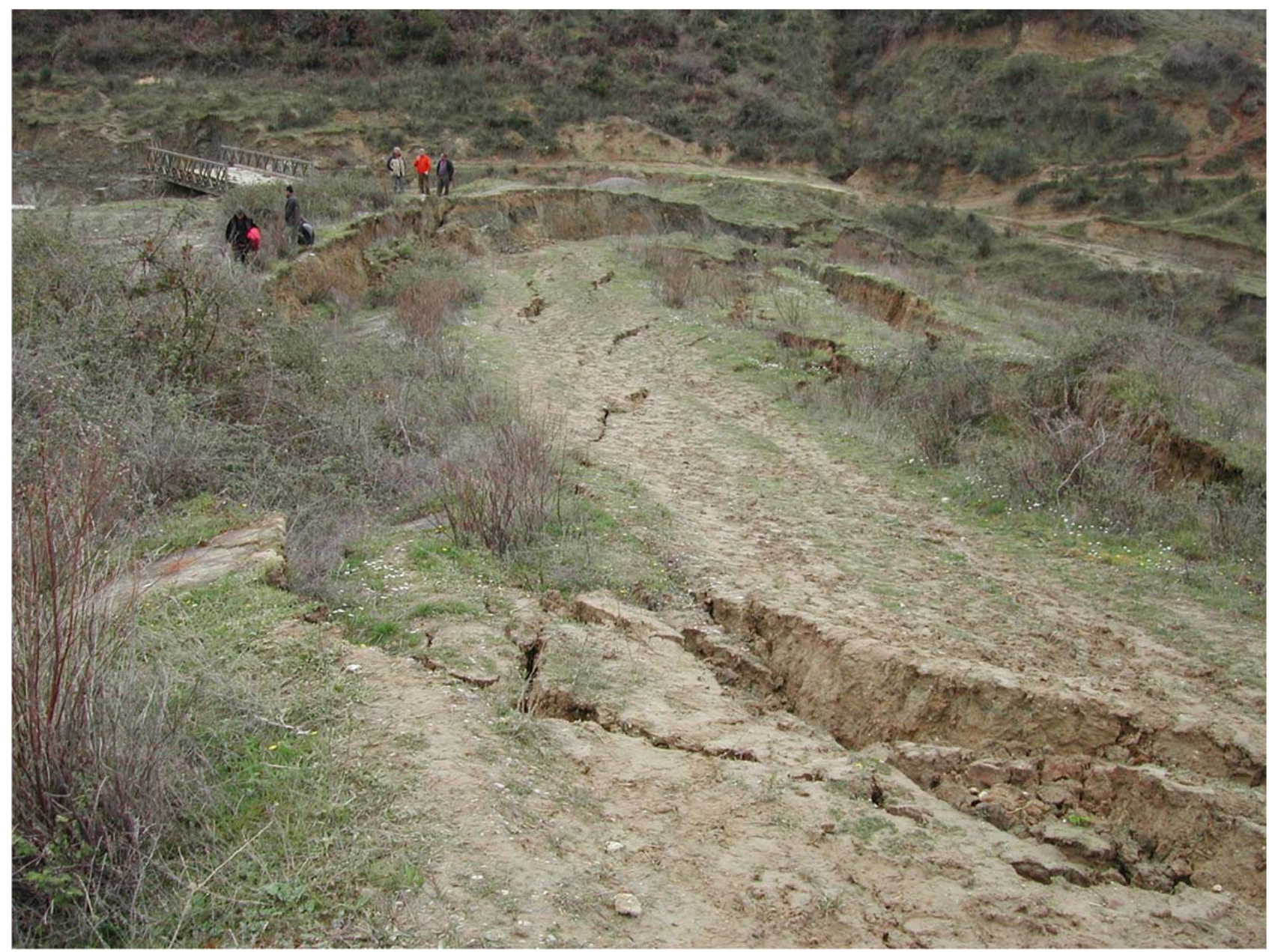

Figure 11: The Sharredushk dam in Albania

\section{Flooding}

A book entitled 'When the Rivers Run Dry' by Fred Pearce was published in 2006. This makes a number of criticisms of dams, but the chapter with which I had most difficulty was entitled 'Dams that cause floods'. I was puzzled by this, as dams do not generally cause floods except in very rare instances such as dam failure or the misoperation of spillway gates; attenuation in the reservoir peak outflow will almost always be less than peak inflow. If the reservoir is partly empty at the start of the storm, the benefit can be very substantial.

In the interests of fairness I should, perhaps, acknowledge that if a dam on a tributary delays the flood peak so that it coincides with that on the main river, then the dam may be said to have made flooding on the main river worse. 


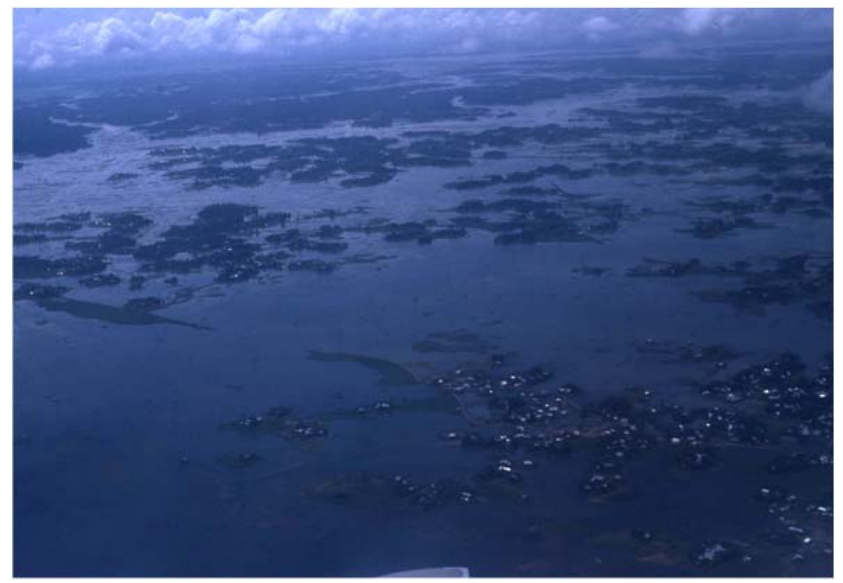

Figure 12: Flooding near Dhaka in Bangladesh

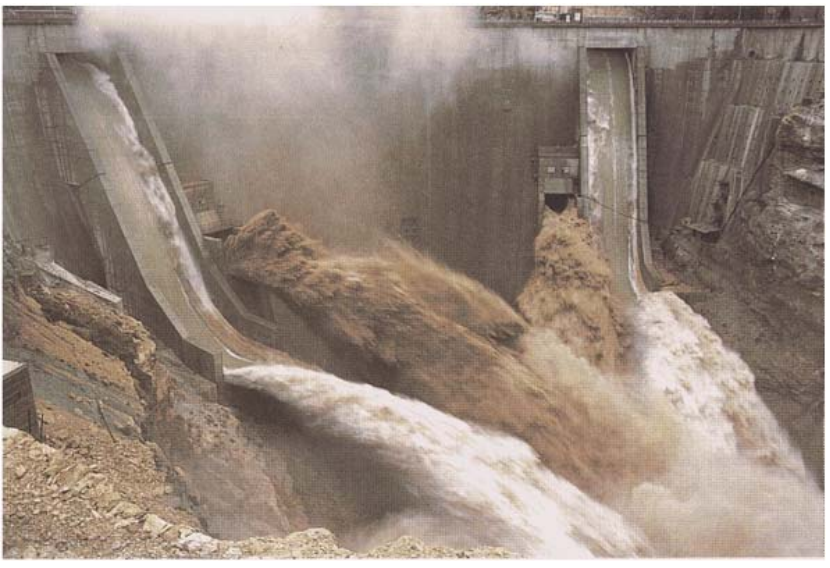

Figure 13: Spillway discharging at the Jiroft dam in Iran

Fred Pearce says: "Most dams are built with the promise that they will capture floodwaters from the rivers that they barricade". I can well believe that people are told that most dams will have flood control benefits, but this is not at all the same thing as saying that there will never be out-of-bank floods downstream in the future. We seem to have a real problem of public perception here, and as designers we have to be very careful to emphasize to the public that certain flooding risks will remain even after the construction of the dam.

The proper operation of the gates is extremely important, and is aided by pre-designed gate operating schedules and/or by computerized assimilation of rain gauge outputs and measurements of flows in the streams entering the reservoir. Mis-operation of gates is uncommon, but not without examples. At the Thap Salao dam in Thailand in 1996, the gates in the gated portion of the spillway were fully opened to protect the damaged, non-gated portion. A bridge was washed away downstream and there was flooding. If it had been possible to operate the gates according to the normal rules, the damage would have been much less.

One of the gates at Sirikit dam in Thailand is shown on the previous page. Because the main power supply can often fail as a result of hurricanes, landslides and so on, it is always important to have a reliable standby system with a full tank of fuel. The standby system should be operated weekly as routine.

In 1986, we studied the problem of flooding in Bangladesh, which is probably the country with the world's worst flooding problems. Figure 12 was taken from the air, approaching Dhaka airport. Out of this study came proposals for seven large dams in Nepal to mitigate flooding in Bangladesh and India, to increase the availability of dry season irrigation water for the benefit of Bangladesh and India, and to generate hydropower for Nepal to sell to India. The easternmost is a 269 m-high dam on the Sapt Kosi, which has a catchment area at the dam site of $61788 \mathrm{~km}^{2}$.

There were disastrous floods on the Sapt Kosi in August 1954 and, more recently, in August 2008 when 2.7 million people were affected. This is why the Sapt Kosi is known as 'The Sorrow of Bihar'.

There are, of course, problems with constructing a large dam at this location, as the area is at risk of earthquakes on the Main Boundary Thrust, where the Indian Plate is being driven into Tibet at a rate of 45 $\mathrm{mm} /$ year.

Probably the largest risk is of earthquake-induced landslides into the reservoir, which is why we originally suggested freeboard of $50 \mathrm{~m}$. 


\section{Cost overruns}

The World Commission on Dams looked at cost overruns on projects and also under-performance in terms of areas irrigated, hydropower generated, and so on. For 81 dams, the WCD obtained an average cost overrun of 21 per cent, when adjusted for inflation.

Unexpected ground conditions are, of course, a common reason for cost overruns, and probably apply more to dams and tunnels than to many other civil engineering projects.

The WCD noted average cost overruns of about 6 per cent for a sample of 64 thermal power projects, where costs are more easily predictable.

\section{Sedimentation}

There is a danger that as dam engineers we will think that we are dealing with water when we are really dealing with water and sediment. Figure 13 shows discharges from the Jiroft dam in Iran.

It is estimated that 0.5 to 1 per cent of the world's reservoir volume is lost each year to sedimentation. However, the problem is very uneven, and sedimentation is a major problem at some reservoirs, particularly where the soils are erodible or the catchment area is large in relation to the capacity of the reservoir.

The Tarbela reservoir on the Indus has a catchment area of $169000 \mathrm{~km} 2$, and is filling with silt at a rate of $200 \times 106$ t/year. The silt there is slowly advancing towards the outlets. Interestingly, sedimentation at Tarbela is actually taking place at a slower rate than originally anticipated.

In a paper on small reservoirs on large catchments in June 2003, I drew attention to the usefulness of dividing the volume of the reservoir by the area of the catchment. This is a very simple calculation, which can also flag up reservoirs where sedimentation is likely to be a problem. It represents, of course, the depth of runoff needed to fill the reservoir from empty.

Table 2 shows reservoirs of greatly different size ranked by the depth of runoff required to fill the reservoir from empty.

Table 2: Reservoirs ranked by depth of runoff required to fill reservoir from empty

\begin{tabular}{|l|c|c|c|}
\hline Reservoir & Capacity $\left(\mathrm{Mm}^{3}\right)$ & Catchment Area $\left(\mathrm{Km}^{2}\right)$ & Runoff to fill $(\mathbf{M m})$ \\
\hline Tunnel End & 0.1 & 13.8 & 7 \\
\hline Three Gorges & 39,300 & $1,000,000$ & 39 \\
\hline Tarbela & 14,000 & 169,000 & 83 \\
\hline Craig Goch & 9.2 & 55.4 & 166 \\
\hline Kariba & 180,000 & 663,000 & 271 \\
\hline Lyn Brianne & 61 & 88 & 693 \\
\hline Claerwen & 48.3 & 53.6 & 901 \\
\hline Clywedog & 50 & 50 & 1,000 \\
\hline
\end{tabular}


The main interest in this Table is the position of the Three Gorges project, where about 40 million tonnes of sediment is deposited in the reservoir each year. Despite the 23 bottom outlet gates, the silt flow to the river downstream is interrupted with possibly detrimental environmental effects, which are discussed in Trevor Turpin's excellent book 'Dam'.

It would not be advisable to rely heavily on this very simple parameter, as there are large variations in the amounts of sediment produced by different catchments and mean annual figures are misleading, as most of the sediment comes down in floods.

The conclusion is that we should think very carefully about the potential sediment problems at reservoirs we plan to build.

\section{Evaporation}

Those opposed to dams often draw attention to the evaporation losses from open water surfaces. This is certainly something that needs to be evaluated carefully at the planning stage of a project. At the Shadala reservoir being planned near the town of Sulay - maniyah in Iraq, annual reservoir evaporation is calculated as $1245 \mathrm{~mm}$ with rainfall of only $690 \mathrm{~mm}$. The net loss of water will thus be $555 \mathrm{~mm} /$ year. Assuming the 5.8 $\mathrm{km} 2$ reservoir to be kept full throughout the year, this represents an average loss of 100 litres/s over the year, or 2 per cent of the average inflow of $4.88 \mathrm{~m}^{3} / \mathrm{s}$.

Evaporation at Lake Nasser is about $10 \mathrm{~km}^{3} / y e a r$, which represents about 11 per cent of the average amount stored. Assuming a reservoir area of $5250 \mathrm{~km}^{2}$, this implies $1900 \mathrm{~mm}$ of evaporation per year, or about 5.2 $\mathrm{mm} /$ day. It is estimated that 18 per cent of Egypt's share of the flow of the Nile is lost in this way.

The question of evaporation is complicated because there would have been some evaporation and evapotranspiration even if the reservoir had never been built.

Table 3: Annual reservoir evaporation

\begin{tabular}{|l|c|c|c|}
\hline Reservoir & Annual evaporation $(\mathbf{M m})$ & Annual rainfall $(\mathbf{m m})$ & Net loss $(\mathbf{M m})$ \\
\hline Shadala, Iraq & 1,245 & 690 & 555 \\
\hline Benghazi, Libya & 1,266 & - & - \\
\hline Lake Nasser, Egypt & 1,900 & ) & 1,900 \\
\hline Bengoh, Malaysia & 1,500 & 4,000 & $-2,500$ \\
\hline
\end{tabular}

\section{Hurricanes}

A hurricane, or typhoon, is a large tropical cyclone with wind speeds greater than $118 \mathrm{~km} / \mathrm{hr}$, although wind speeds can, in extreme cases, exceed $300 \mathrm{~km} / \mathrm{hr}$. They can form when the sea temperature exceeds $26^{\circ} \mathrm{C}$. The most favoured starting latitude is $14^{\circ}$ north or south of the equator. Very few hurricanes start more than $25^{\circ}$ from the equator.

Because hurricanes need heat energy from the sea, those in the northern hemisphere occur mostly in the months of August, September and October. Usually they die out quite quickly over land, although some, like Hurricane Mitch, have penetrated quite far inland.

There are two reasons why we are interested in hurricanes: 
- the high winds can generate large waves, which can overtop a dam, damage the wave protection and bring down power lines; and,

- the high rainfall typically associated with a hurricane can cause large spillway floods, landslides and sedimentation in the reservoir.

During Hurricane Fifi in Honduras in September 1975 there was about $500 \mathrm{~mm}$ rainfall in 24 hours and in Hurricane Mitch in 1998 there was about 1000 mm in 48 hours.

With modern satellite imagery there should be scope to lower water levels in advance of a hurricane, but unfortunately they can change direction at the last minute. This is what happened with Hurricane Tomas on 30 October 2010. There was $533.3 \mathrm{~mm}$ of rainfall that day at Castries airport, and probably a good deal more up in the hills. This hurricane was unusually late in the season and caused much damage on St. Lucia.

\section{Social benefits of multipurpose hydro}

We have looked at the usefulness of dams and also problems associated with dams, and we may even be ready to say, with Professor David Grey, "I am for good dams and against bad dams". In November 2000, the WCD put forward guidelines for building a sound and environmentally friendly dam.

Since then the Nam Theun 2 hydropower project has been built in Laos, with funding from the World Bank, the Asian Development Bank, Agence Française de Développement, the European Investment Bank and the Nordic Investment Bank.

The project cost US $\$ 1.45$ billion, and has an installed capacity of $1075 \mathrm{MW}$, of which $1000 \mathrm{MW}$ is for export to Thailand and the remaining $75 \mathrm{MW}$ is for domestic consumption in Laos. The catchment area is $4039 \mathrm{~km}^{2}$ and there is a $39 \mathrm{~m}$-high dam to divert most of the water, via a tunnel and shaft to a power station in a neighbouring catchment, where use can be made of a head of $348 \mathrm{~m}$. The reservoir has an area of $450 \mathrm{~km}^{2}$ and 6200 people had to be resettled.

The project set various goals other than the generation of hydropower and seems to have achieved considerable success in alleviating the poverty of people in the area.

\section{The modern dam engineer}

So we can now attempt a description of the modern dam engineer. The first thing to note is that he is probably Chinese, Indian or Brazilian, since these are now the most active countries for dam building. Having said this I have no doubt that British and other European engineers will still have a significant part to play in the future, but it is no good resting on our laurels. We have to convince people that engineers whose countries peaked in dam engineering some years ago still have something valuable to offer around the world in the way of sound engineering and a professional outlook.

What do we mean by 'professional'? No doubt the term will mean different things to different people. To the water company employee charged with looking after a portfolio of dams, it will suggest his diligence in his task and the way he will put his duty before personal considerations. I can never think of this without recalling some of the engineers I have met in the former Soviet Union, who worked with complete dedication for small wages. Nor was I surprised to read about the engineers who went into the reactor at Chernobyl to make it safe, knowing that to do so implied certain death. Similar stories came from Fukushima in Japan and from the World Trade Centre in New York. 
Then there are the engineers who work for consultants. For them professionalism will mean giving the best possible advice in the best interests of their client. Then there are the engineers who work for contractors or academic institutions. A lot of the really clever things are achieved in the universities, and we can benefit from this knowledge.

In the UK we have a good system for training dam engineers and for appointing them to the appropriate panels. Much effort goes into this and, in my experience, the appointees invariably have a very responsible attitude to their work. For me the strongest aspect of the British system is the individual responsibility placed on the Panel Engineer. If, for example, you are appointed as Construction Engineer for a reservoir, you know that you are going to be held personally responsible for anything that goes wrong.

What we do is, of course, a very small part of engineering in the UK, for which there are some good signs and also some that are very worrying. In his 2004 Richard Dimbleby lecture, Sir James Dyson argued that we cannot rely on service industries to keep the country afloat and that "engineering is this country's future". I think that Sir James has a point about the importance of science and engineering to our country and the need for this to be recognized by government. I think, however, that we can say that dam engineers in the UK are doing their bit, and I hope very much that good young engineers will continue to enter our part of the civil engineering profession.

\section{Bibliography}

Alderwish A.M. and Alderwish W.I.M, 2010, "Integrated Water Management for Small Catchments in Arid Mountainous Region - Yemen".

Binnie G.M, 1987, "Early Dam Builders in Britain”, Thomas Telford, London.

British Medical Journal, 2011. "Assessing the health benefits of tackling climate change" ( Editorial ), 22 October.

Hieatt M, Shah S.R.A, Khan R.A, Ali M, Asghar N, Sheikh S, Mason P.J, Molyneux J.D, Khan G.R, Humayun I.A, 2012, "Some Geotechnical Aspects of Raising the Mangla Dam, Pakistan", Geotechnical Engineering, Volume 165, Issue GE3, June.

Hinks.J.L, Spasic-Gril L. and Palmer M.J., 2012, "Behaviour of Embankment Dams in Earthquakes", Proceedings of British Dam Society Conference, Leeds, September.

Hinks J.L, Wieland M. and Matsumoto N, 2012, "Seismic Behaviour of Dams", ICOLD Symposium in Kyoto, Japan, 5 June.

Hinks, J.L, Lewin J. and Warren A.L, 2003, "Extreme Events and Reservoir Safety", Dams and Reservoirs, Vol 13, No. 3, October.

Hinks J.L., 2003, "Small Reservoirs on Large Catchments", Dams and Reservoirs, Vol 13, No. 2, June.

Lempérière F. and Lafitte R., 2006, "The role of dams in the XXI century to achieve a sustainable development target". In Dams and Reservoirs, Societies and Environment in the 21st century ( Berga L, Bulli J.M. Bofill E et al ( eds)), Taylor and Francis, London.

Pearce F, 2006, "When the Rivers Run Dry", Transworld Publishers, London.

Turpin T, 2008, "Dam", Reaktion Books Ltd, London

World Commission on Dams, 2000, "Dams and Development", Earthscan, November. 